\title{
The Role of Leader in Monarchy Evolution: Morocco Under King Mohammed VI
}

\author{
Renata Salamova ${ }^{1, *}$ \\ ${ }^{1}$ Faculty of Humanities and Social Sciences, Russian Peoples' Friendship University, Moscow, Russia \\ *Corresponding author. Email: renatasalamova@hotmail.com
}

\begin{abstract}
This article is devoted to the analysis of an idea about the nature and essence of the political life of Morocco, based on searching of an appropriate model of democratization while retaining the monarchy presented by the strong personality of Mohammed VI, King of Morocco. The rise to power and the elaboration of the political course of King Mohammed VI plays a fundamental role in the historical and political definitions of the existence of the monarchist system of the state as the legacy of King Hassan II. The monarch plays a crucial role in the sociopolitical life of the country and is the guarantor of the evolution of monarchist power in Morocco from absolute to constitutional way of governing. This justifies the exclusivity of the chosen course of democratization "in Moroccan way" on the basis of the preservation of traditions and sacred foundations of society.
\end{abstract}

Keywords: Monarchy, Democratization, Evolution of political system, Muslim oriental monarchist country, National idea: cultural and religious particularities.

\section{INTRODUCTION}

The Kingdom of Morocco is the only country in North Africa that has maintained a largely traditional form of governing after independence. In the Mediterranean during a long period countries located in the southern part of the region remained under the control of other states. Morocco, Algeria and Tunisia were colonized by France, Libya by Italy and Egypt by Great Britain [1]. At independence Morocco remained a monarchy with a quasi-liberal economic system [2]. The main time the monarchical system of the Moroccan state largely determines the foundations of political culture and contributes to the preservation of the traditional forms of national consciousness. The slogan - "God, Homeland, King" - is the basis of political behavior of the country's population.

This form of organization predetermined the particularities of the political structure of this state in comparison with other African countries, which, in their absolute majority, are republics. At the same time, it is completely different from its European counterparts. Although the Kingdom has a parliament and a constitution, relations between the King and other institutions of the Moroccan political system are specific: the terms of reference and real power of the King are much wider and weigh comparing to the similar functions of European monarchs. This is what affected the formation of the statehood of the Kingdom.

\section{MONARCHY AS TRADITIONAL GIVEN}

With the death of King Hassan II, the ruler who played the role of the most important structural factor in society, an entire era in the formation of Moroccan statehood ended. The young King Mohammed VI, born on August 21, 1963, ascended the throne.

Despite the stability and predestination of Morocco's half-century-long political course, in recent decades, starting with the coming to power of King Mohammed VI, the question of modernizing of the political system and the emergence of new elements of Moroccan political culture based on national traditions often arises. Obviously, all these changes are related both to the internal evolution of society and to the external changes taking place in the whole world.

Before finding a solution on reform issues, it is necessary to determine the level of the country's 
capacity based on the historical state policy. It can be assumed that the level of capacity of the country as a whole is determined in issues of trade and economic indicators, social development, the state of the cultural and religious values base of society, as well as recognition of Morocco in the international arena. Human capacity assessment can be presented in the following five main areas: as the potential of the people; as the capacity of the State; as life and intellectual potential; as potential forces to increase wealth; as potential resources and foundations for humanitarian development.

Basing on these indicators, it is supposed that the phenomenon of the monarchy based on the strong personality of the King is perceived by the Moroccan population as a traditional historical given. This fact is an element of culture, which shows that the whole Moroccan system does not need to be fully adapted to the requirements of the modern Western world.

\section{TRANSIT DEVELOPMENT VECTORS IN MOROCCO}

Meanwhile, the answer to the question whether it is possible to effectively reform the modern state of Morocco, and to shift the European model of democracy and the rule of law to an initially traditional Moroccan society, is obvious. Morocco is represented as an Arab-Muslim country in the process of democratic transit, but at the same time not quite suitable and not intended to achieve the European parameters of democratization.

The particularities of political processes in Morocco at the present time are manifested in solving the difficulties and problems that arise in the way of liberalization and modernization, combined with the existing monarchist system, a political understanding of the possible prospects for the further development of relations within the Maghreb region itself, the resolution of the Western Sahara conflict and Morocco-EU relations [3].

It is known, back in the early 90s, under King Hassan II, Morocco began a reform process that was supposed to affect all sectors of life of the population in order to modernize the political, economic and social spheres of life of the country. But only under Mohammed VI these processes really started to take place.

All these developmental vectors can be shortly presented in the following aspects:

- The rise to power and the elaboration of the political course of King Mohammed VI play a fundamental role in the historical and political definitions of the existence of the monarchist system of the state as the legacy of King Hassan II. The monarch plays a crucial role in the socio-political life of the country and is the guarantor of the evolution of monarchist power in Morocco from absolute to constitutional way of governing. This justifies the exclusivity of the chosen course of democratization "in Moroccan way" on the basis of the preservation of traditions and sacred foundations of society. Modern Morocco is a constitutional monarchy where the monarch shares his power with the legislature [4]. During the two decades of his reign, the King established himself as a young statesman, objectively assessing the current situation in the country and at the same time having a strategic vision, thoughtfully and persistently implementing the taken decisions. As head of state, the monarch has very wide powers, which allows him to exert a decisive influence on the country's domestic and foreign policy.

- The basis of the legal and institutional framework of Moroccan law, presented in the Constitution of the State and institutional mechanisms, are the key to the successful reform of various sectors of society. At the moment, it is obvious that in the hands of the young King, the rights and freedoms of the population significantly increased, foreign capital came into the country. The legal state is in process of formation. Morocco is regarded as one of the most advanced states in terms of freedoms and democracy in Africa and in the Arab world. The King's rise to power marked the beginning of political liberalization. If the democratic process develops in stages and progressively, then later it supposes to have more political guarantees and confidence in the stability of the adopted course.

- The trade and economic development of modern Morocco within the framework of a given political course under the influence of the global economic crisis, has its own pace of development, and the effectiveness of implementing reforms in the social and penitentiary spheres largely depends on the effectiveness of solutions, especially, to migration issues as the main "pain" issues of the Kingdom.

- The cultural and religious components of modern Morocco have a direct influence on both the domestic and foreign policies of the 
state. Islam and the "multiculturalism" are the sacred foundations of Moroccan society, which play an important role in the formation of elements of political culture. The fact of the gradual displacement of religion from politics has the fundamental importance, reducing its role to the factor ensuring the preservation of the nationalcultural identity of Moroccans. It should be noted here that at a time of increasing of the international terrorism phenomenon, primarily under Islamic slogans, the minimization of the Islamist threat became one of the most important achievements of the head of state. Meanwhile, the attitude of Islamic forces to secularism, which they have always considered an "ideological enemy", remains the most complicated issued in all the Arab countries [5].

- The monarchy in Morocco is also reflected in the context of international relations and the main directions of the state's foreign policy as an attempt to respond to the global challenges of our time, as at the regional level in proposal to grant autonomy to the Western Sahara region, in relations with other North African states and in freezing of development of the Arab Maghreb Union in a contemporary geopolitical context, and in the European direction - in Morocco's success on the path of increasing rapprochement with European countries with the acquisition of special status under the EU.

- The characteristics of Moroccan state, represented by a strong leader, are the key to political success in a long term. The concrete results achieved by the Kingdom during the two decades show the historically established value foundations in the modernized version.

\section{ECONOMIC AND SOCIAL CHALLENGES}

In the twenty years since then, Morocco has made significant strides in several areas of economic and human development [6].

The King pays considerable attention to eradicating of the integrism causes - reducing the number of people living in poverty, increasing the well-being of the middle class and developing the backward areas of the south that served as an Islamists stronghold. Morocco actively participates in ecological projects. Under the royal pressure and its financial capacities, the Kingdom multiplies large-scale solar and wind projects [7].
Considering the economic sphere, it would be false to claim that Morocco has not been affected by the global financial and economic crisis of recent years and especially pandemic issues. A country with a weak middle class has to depend on the foreign investment which is not evident at the moment. But it should be noted that the first decade of the $21 \mathrm{st}$ century was positively marked by favorable financial factors for Morocco in the form of European and Arab expensive projects, the rapid development of the tourism sector, as well as active cash transfers of Moroccans living abroad. But this situation is not an indicator of the economic stability of a state that does not have its own monetary fund.

Thus, the permanent possibility of an economic crisis is an always existed potential threat to the Kingdom. The reasons of this possible crisis are out of Moroccan control: falling phosphate prices, caused by the recession of the world economy, curtailment of exports, rising cost of imported food, reduced tourism or sharp fluctuations in foreign exchange rates and destabilization of international financial markets. At the same time, Morocco remains connected, through the structure of its trade and financial relations, with Europe, to a region which faces structural difficulties and whose growth prospects remain unfavorable [8].

Unemployment and the quality of education also continue to be serious social problems. These problems are especially important for young people. Politically, the danger of such a situation is that unemployed youth are receptive to the ideas of religious revival and therefore receive close attention from Islamists. Socially and culturally, this situation leads to degradation of the foundations of modern Moroccan society, consisting mostly of young people, who sooner or later rebel due to the absence of the social sector reforming results.

\section{CONCLUSION}

At the beginning of the 21st century, all the North African countries, including Morocco, had achieved impressive results in political, economic, social and cultural development. Meanwhile most of them passed by Arab Awakening which promised to be a long and painful process, during which the countries in the region had a possibility to experience more change and turmoil [9]. Now it can be said that this process did not affect Morocco as much as other countries. Possibly because of the fact that the colonial and dependent political state was replaced by a sovereign which intends to maintain several irregular ongoing democratization processes in the 
frame of its proper political system which stays intact. This logic presents favorable prospects, but there are many serious problems that can slow down or even reverse the ongoing processes of modernization. The results of global evolutionary process prove the fact of decrease of its separate geopolitical role and the breakdown into a number of areas with regional leaders with their goals and action programs. In this sense, it can be supposed that at the beginning of the 21 st century the Kingdom of Morocco firmly takes the position of leader in the North African region with a strong leader Mohammed VI.

There is a common idea that Mohammed VI, compared to his father, began to pursue a more open policy, takes more decisive steps towards the countries of the West and the North Africa, and actively participates in projects of EuroMediterranean integration and the Union of the Arab Maghreb.

The increasing internal political stability and evolution towards further democratization increases the predictability of the foreign policy in the country. Morocco is guided by the combined concept of equilibrium and multilateral economic cooperation, which works well, helping the Kingdom to maintain a firm partnership around the world.

Morocco's success in the European direction cannot be underestimated neither. Obtaining the socalled special status under the EU gives Morocco that long-awaited chance to develop and implement exclusive relations with European countries, and also allows to predict the main vector of Morocco's foreign policy development in the coming years. Indeed, as mentioned above, the recognition by the European community of Morocco's achievements in the process of democratization of the country, liberalization of the economy and the situation of human rights is only a guarantee of partnership, the success of which depends on the effectiveness of the interaction of both parties, but still more on the efforts of the kingdom itself and its ability to adequately respond to the European challenge.

Thus, the king of Morocco presents Kingdom's future as depended to a large extent on how democratization will proceed, even if in its Moroccan version, based on a combination of traditionalism and modernization. It can be assumed that as the economy continues to develop, the need to overcome clan domination and ensure freedom of economic competition will begin to emerge, which cannot be achieved without free political competition. In this situation, King Mohammed VI will need to go through the "razor blade," not delaying with overdue reforms, but also avoiding their forcing.

Despite the always-presented criticism of the situation and all that remains to be done in terms of the reforms conceived by the King, it should be noted that Morocco has significantly succeeded in the process of political transit and has taken the role of leader in the North African region. It must be recognized that, at its own level, in its geopolitical situation and its values, Morocco in the hands of the King has taken a great step towards democratic transit, which is a part of the global logic of the Kingdom's integration into an association of nations respecting the values, norms and standards of democracy. It is supposed to be a political and trade pluralism, open economic development, reforming the social sector and tolerance and respect for diversity in the cultural and religious spheres. All these basic vectors of development were somehow chosen at independence. But due to the political context, they were not fully realized, forming the basis of Morocco's political course for these last decades and coming years.

\section{AUTHORS' CONTRIBUTIONS}

This paper is independently completed by Renata Salamova, who contributed to the design and implementation of the research, to the analysis of the results and to the writing of the manuscript.

\section{REFERENCES}

[1] J. Norwich. The Middle Sea. A history of the Mediterranean. - Moscow: AST Publishers, 2010, p. 771.

[2] Y. Zoubir. The Algerian-Moroccan Rivalry: Constructing the Imaginary Enemy in Shocks and Rivalries in the Middle East and North Africa., Imad Mansour \& William Thompson Ed., Georgetown University Press, 2020, p. 183.

[3] J. Kerdoudi. Relations Maroc - UE: quels enjeux? // L'Economiste Magazine. Casablanca, 2021, №5960.

[4] A. D. Voskressenski. Political systems and democracy models in the East. - Moscow: Aspect press, 2007, p. 52.

[5] Transformation in the Arab world and Russia's interests. // Valdai discussion club analytical report. Moscow, june 2012, p. 45. 
[6] S. Feuer, R. Ayadi. Twenty years under king Mohammed VI (part 1): domestic developments,

https://www.washingtoninstitute.org/policyanalysis/twenty-years-under-king-mohammedvi-part-1-domestic-developments [accessed date: 10.04 .2021$]$.

[7] In the age of the "green economy" // Jeune Afrique, March 2021, №3098, p. 97.

[8] P.-R. Agenor, K. El Aynaoui. Morocco Growth strategy by 2025 in a changing international environment,

https://www.policycenter.ma/sites/default/files /livre_ocp_web3.pdf [accessed date: 14.04.2021].

[9] Islam in politics: ideology or pragmatism? // Valdai discussion club analytical report. Moscow, august 2013, p. 107. 